\title{
CERTAIN ASPECTS ON REPRODUCTIVE POTENTIAL AND FEEDING CAPACITY OF THE SPIDER CHIRACANTHIUM INCLUSUM HENTZ (ARACHNIDA: MITURGIDAE)
}

\author{
ABU-ZAED, AMAL E., MERVAT A. KANDEL AND A. A. A. EL-SAYED
}

Plant Protection Research Institute, ARC, Dokki Giza

(Manuscript received 14 March 2010)

\begin{abstract}
Studies were carried out under laboratory conditions at $25 \pm 1$ ${ }^{\circ} \mathrm{C}$ and $65-70 \%$ R.H. to study the effect of two species of Lepidopterous insects, Pectinophora gossypiella and Spodoptera littoralis on biological aspects of the spider Chiracanthium inclusum. $P$. gossypiella was the best as it reduced in duration of different predator stages, whereas, P. gossypiella increased the fecundity, as well as increasing consumption prey. While, female deposited average 134.3 eggs/sac when fed on P. gossypiella and 97.6 eggs/sac on $S$. littoralis, respectively. On the contrary, female longevity lasted 114.0 days, while, male adult hood lasted 75.0 days on $P$. gossypiella, and 135.0 days and 98.3 days for both sexes on $S$. littoralis, respectively. The female and male predator consumed 348.3 and190.6 prey of P. gossypiella and 411.66 and 217.33 prey of $S$. littoralis, respectively.
\end{abstract}

\section{INTRODUCTION}

Winter spider (Chiracanthium inclusum Hentz) is a nocturnal collected running spider that is often one of the most numerous spiders collected in crops such as, cotton and citrus Whitcamb et al. 1963 and Amalin et al. 2001. Nyffeler et al. 1990 and Miliczky and Calkins (2002) reported that it is know to prey the eggs of Helicoverpa zea and the eggs of other crop pests. On the other hand, Taylor and Pfannenstid (2008) demonstrated that a large proport of the spider $C$. inclusum collected at night from cotton fields showed that it had fed on extra floral nectar. In addition, other species of Chiracanthium were reported in significant numbers in cotton fields in the USA (Whitcamb and Bell 1964). However, Ruiz (2006) reared Chiracanthium inclusum on eggs of $H$. zea and scale insects as a prey and observed it to be with cotton bollworm. In 2008 Pfannenstiel et al. studied the effect of nectar and egg of $H$. zea on feeding, immatures duration and adult longevity of the spider $C$. inclusum.

Therefore the aim this research was to examine the effect of two cotton pests $P$. gossypiella and $S$. littoralis on some biological developmental stages, feeding capacity and fecundity of the spider $C$. inclusum in order to better understand its role, as a natural enemy of insect pests in cotton fields. 


\section{MATERIALS AND METHODS}

\section{Prey used}

The two insect species of prey used in this study were Pectinophora gossypiella (PBW) and Spodoptera littoralis. Eggs and larvae of pink bollworm, P. gossypiella were reared under controlled conditions $\left(25 \pm 1^{\circ} \mathrm{C}\right.$ and $65-70 \%$ R.H. with complete dark all day time) for several generations on a semi- artificial diet according to Rashad and Ammar (1985). On the other hand, larvae of $S$. littoralis were reared on the castor bean leaves.

\section{The spider $C$. inclusum}

Laboratory culture of $C$. inclusum began with adults and egg sacs collected at the end of August and mid September from cotton fields at Mansoura region Dakahalyia Governorate and kept under the laboratory conditions. The predator was reared for one generation on eggs $+1^{\text {st }}$ instar larvae of PBW and $2^{\text {nd }}$ instar larvae of S. littoralis.

\section{Feeding capacity}

To rearing the winter spider 90 individuals spiderling were reared from eggs to maturity on different prey. 90 newly emerged $C$. inclusum spiderling were placed individually in glass tubes (15 $\mathrm{cm}$ high $X 1.5 \mathrm{~cm}$ wide) with sufficient numbers of the two spotted spider mite $T$. urticae were offered daily until the end of $1^{\text {st }}$ instar spiderling. After that, these tubes were divided in two groups, each of 45 tubes. Sufficient numbers of eggs and newly hatched larvae of PBW were offered daily to first group, while, the second group was offered the $2^{\text {nd }}$ instar larvae of $S$. littoralis. The numbers offered from each prey were increased as the predator's spiderling grew older. The numbers of consumed prey from each PBW and $S$. littoralis were recorded daily.

Also, the numbers of deposited egg sacs and the number of deposited eggs inside sacs were counted as well as pre ovipostion, ovipostion, post ovipostion, longevity of females and male estimated. The total consumptions were assessed. The relation between duration of different stages and adult longevity, also, total of consumption for each prey were examined by analysis of variance (ANOVA) using Costat program.

\section{RESULTS AND DISCUSSION}

\section{Developmental time of spiderling stage}

Development of spiderling Chiracanthium inclusum passes through seven instars. Duration of these instars were affected by different foods. As shown in Table (1), the 
total developmental periods were highly significant shorter for spiderlings reared on eggs + first instar larvae of Pectinophora gossypiella (127.93 days) while, being longer (146.39 days) when reared on $S$. littorals for completion of development, respectively. Obtained results indicated that rearing on $P$. gossypiella decreased developmental time by $12.5 \%$ than rearing on $S$. littorals.

\section{Feeding Capacity}

The results in Table (2) showed that the highly significant difference occurred in feeding capacity of $C$. inclusum between spiderlings instars $2^{\text {nd }}-7^{\text {th }}$ when fed on mixed of (eggs $+1^{\text {st }}$ instar larvae) of $P$. gossypiella and $2^{\text {nd }}$ instar larvae of $S$. littorals. Obtained data cleared that the mean consumption rate increased with the progressive of spiderling age. Also, data analysis in Table (2) revealed that the average of total consumption of the tested predator $C$. inclusum from $\left(2^{\text {nd }}-7^{\text {th }}\right)$ instars fed on each of the two preys $P$. gossypiella \& S. littorals were 514.0 and 325.0 prey, respectively.

Under standard laboratory conditions, adult female and male of $C$. inclusum lived an average of $114 \& 75$ days, when reared on P. gossypiella while, the averaged of 135 and 98.3 when feeding on S. littoralis, respectively (table, 3 ).

Mansour et al. (1980) reared the spider Chiracanthium mildi on the prey S. littoralis larvae. Females required a mean of 231.0 days from hatching to mature, reached adult after 9-10 months, and lived for an average of 240 days as adult. Male required 185.0 days from hatching to reach maturity, becoming adult after 7-8 months, and lived for an average of 73.0 days as adult. When rearing $C$. jsvium on Ceratitis capitata, Sallam (1996) stated that eggs incubation period averaged 14.06 days and the total life span was 387.62 and 234.73 days for female and male, respectively.

\section{Ovipostional period}

Table (3) showed that high significant differences occurred between preovipostion, ovipostion and post ovipostion periods for $C$. inclusum when reared on (eggs+ larvae) of P. gossypiella, these periods averaged 19.1, 30.3 and 64.3 days, respectively, while, prolonged to $24.6,38.3$ and 72.0 , respectively when adult female fed on $2^{\text {nd }}$ instar larvae of $S$. littoralis at the same pattern.

\section{Number of deposited eggs/female}

Data in Table (3) revealed that the number of deposited eggs/sac was affected by prey. This average was higher for female fed on eggs+larvae of PBW. Also, data analyses showed a highly significant differences between the average number of deposited eggs, whereas, female deposited 134.3 and 97.6 eggs when it fed on PBW and $S$. littoralis, respectively. Also, high significant differences occurred between eggs/sac hatchability percentages when female fed on PBW and S. littoralis, 
where by, hatching percentages were 93.96 and $82.16 \%$, when female fed on the above mentioned prey, respectively.

Edwared (1958) recorded 112 eggs in a single egg/sac produced by $C$. inclusum, while, Peck and Whitcomb (1970) reported the occurrence a range of 17-86 eggs per sac. However they stated that Chiracanthium spiderlings appeared to fed on the infertile eggs in their egg mass. The $1^{\text {st }}$ instar spiderling fed on larvae of $T$. cinnabarinus and 1-day old S. littoralis larvae. Amalin et al. (2001) reared C. inclusum on citrus leaf miner larvae, female produced 1-3 egg masses with an average of 57 eggs per egg mass. Ovipostion took place 2-7 days after mating.

\section{Incubation periods of eggs}

At $25 \pm 1^{\circ} \mathrm{C}$ and $65-70 \%$ R.H. egg incubation averaged 13.23 days and 18.61 days when females reared on PBW and $S$. littoralis, respectively.

Data indicated that rearing females on $P$. gossypiella shortened adult longevity by $15.6 \%$ time and increased number of eggs per sac eggs by $27.4 \%$ than that females reared on S. littoralis Table (3). 
Table 1. Development of immature stages of Chiracanthium inclusum when fed on different prey at $25 \pm 1^{\circ} \mathrm{C}$ and $65-70 \%$ R.H.

\begin{tabular}{|c|c|c|c|c|c|c|c|c|c|}
\hline prey & $1^{\text {st instar }}$ & prey & $2^{\text {nd }}$ instar & $3^{\text {rd instar }}$ & $4^{\text {th }}$ instar & $5^{\text {th }}$ instar & $6^{\text {th }}$ instar & $7^{\text {th }}$ instar & $\begin{array}{c}\text { Total immature } \\
\text { stage }\end{array}$ \\
\hline \multirow{4}{*}{ 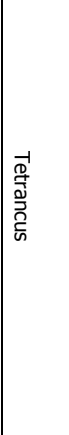 } & \multirow{4}{*}{$9.30 \pm 0.3$} & PBW & $15.67 \pm 0.1$ & $11.33 \pm 0.13 \mathrm{~b}$ & $23.67 \pm 0.2 b$ & $19.33 \pm 0.12$ & $26.33 \pm 0.31$ & $22.3 \pm 0.61$ & $127.93 \pm 2.9 b$ \\
\hline & & $\begin{array}{c}\text { S. } \\
\text { littoralis }\end{array}$ & $17.1 \pm 0.2$ & $15.67 \pm 0.2 \mathrm{a}$ & $27.67 \pm 0.5 a$ & $28.0 \pm 0.4$ & $25.6 \pm 0.7$ & $25.0 \pm 0.3$ & $146.39 \pm 1.79 a$ \\
\hline & & $\mathrm{p}$ & Ns & $0.01 *$ & $0.009 * *$ & Ns & Ns & $0.0048 * *$ & $0.0005^{* * *}$ \\
\hline & & LSD & & 2.61 & 2.28 & & & 1.49 & 4.84 \\
\hline
\end{tabular}

Table 2. food consumption of the spider $S$. littoralis $C$. inclusum during its immature stages at $25 \pm 1^{\circ} \mathrm{C}$ and $65-70 \%$ R.H.

\begin{tabular}{|c|c|c|c|c|c|c|c|c|c|}
\hline Prey & $1^{15 t}$ instar & prey & $2^{\text {nd }}$ & $3^{\text {rd }}$ & $4^{\text {th }}$ & $5^{\text {th }}$ & $6^{\text {th }}$ & $7^{\text {th }}$ & $\begin{array}{c}\text { Total } \\
\text { immature } \\
\text { stage }\end{array}$ \\
\hline \multirow{4}{*}{ 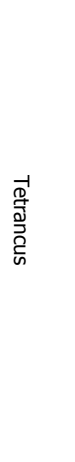 } & \multirow{4}{*}{$43.3 \pm 4.49$} & PBW & $42.66 \pm 2.4$ & $57.0 \pm 1.5 \mathrm{a}$ & $75.6 \pm a$ & $79.7 \pm 0.5 a$ & $110.7 \pm 1.6 a$ & $148.6 \pm 1.15 a$ & $514.0 \pm 3.05 a$ \\
\hline & & $\begin{array}{c}S . \\
\text { littoralis }\end{array}$ & $38.3 \pm 2.6$ & $40.0 \pm 2.3 \mathrm{~b}$ & $40.6 \pm 1.8 \mathrm{~b}$ & $56.0 \pm 3.1 \mathrm{~b}$ & $65 . .6 \pm 1.9 \mathrm{~b}$ & $74.3 \pm 2.3 \mathrm{~b}$ & $315.0 \pm 5.2 \mathrm{~b}$ \\
\hline & & $\mathrm{p}$ & Ns & $0.003 * *$ & $0.0022^{* *}$ & $0.0015^{* *}$ & $0.000 * * *$ & $0.000 * * *$ & $0.000 * * *$ \\
\hline & & LSD & & 7.68 & 13.94 & 8.53 & 8.43 & 6.73 & 25.51 \\
\hline
\end{tabular}


Table 3. Effect of different prey on fecundity and longevity of the spider Chiracanthium inclusum at $25 \pm 1^{\circ} \mathrm{C}$ and $65-70 \%$ R.H.

\begin{tabular}{|c|c|c|c|c|c|c|c|c|}
\hline \multirow{2}{*}{ Preys } & \multicolumn{3}{|c|}{ Ovipositional period } & \multirow{2}{*}{ Total eggs } & \multirow{2}{*}{ Hatching \% } & \multirow{2}{*}{$\begin{array}{c}\text { Incubation } \\
\text { period }\end{array}$} & \multicolumn{2}{|c|}{ Adult longevity } \\
\hline & $\begin{array}{c}\text { Pre- } \\
\text { ovipostion }\end{array}$ & Ovipostion & $\begin{array}{c}\text { Post } \\
\text { ovipostion }\end{array}$ & & & & 우우 & 80 \\
\hline PBW & $19.1 \pm 0.5 b$ & $30.3 \pm 0.3 b$ & $64.3 \pm 0.6 b$ & $134.3 \pm 3.9 a$ & $93.96 \pm 0.5 a$ & $13.23 \pm 0.5 b$ & $113.7 \pm 1.7 b$ & $75.0 \pm 0.5 b$ \\
\hline $\begin{array}{c}S . \\
\text { littorali } \\
s \\
\end{array}$ & $24.6 \pm 0.3 a$ & $38.3 \pm 0.30 a$ & $72.0 \pm 1.7 a$ & $97.6 \pm 2.2 b$ & $82.16 \pm 0.13 b$ & $18.61 \pm 0.1 a$ & $134.9 \pm 1.7 a$ & $98.3 \pm 0.4 a$ \\
\hline $\mathrm{p}$ & $0.001 * *$ & $0.0001 * * *$ & $0.014 *$ & $0.0008^{* * *}$ & $0.000 * * *$ & $0.002 * *$ & $0.0003 * * *$ & $0.000 * * *$ \\
\hline LSD & 1.85 & 1.30 & 5.15 & 11.18 & 1.64 & 2.26 & 5.15 & 1.01 \\
\hline
\end{tabular}

\section{REFERENCES}

1. Amalin, D.M., J.E., Pena, J. Reiskind, and R. McSorley. 2001. Comparison of the survival of three species of sac spiders on natural and artificial diets. J. Arachnology, 29:253-263.

2. Amalin, D.M., J., Reisk, J.E. Pena and R.McSorley. 2001. Predatory behavior of three species of sac spider attacking citrus leaf miner. J. of Acarology, 29: 72-81.

3. Carrol, D.P. 1980. Biological notes on the spiders of some citrus groves in central and southern California. Entomol. News, 91: 147-154.

4. Greenstone, M.H. and K.D. Sunderland. 1999. Why a symposium on spiders in agro ecosystems now? PP. 267-267. In Proceeding, $15^{\text {th }}$ International Congress of Arachnology and Symposium on Spiders in Agro ecosystems, 27 June-3July, 1998 Chicago II.

5. Mansour, F., D. Rosen and A. Shulov. 1980. Biology of the spider Chiracanthium mileid (Arachnida : Clubionidae ). Entomophaga, 25 (3) : 237-248.

6. Miliczky, E.R. and C.O. Calkins. 2002. Spiders (Araneae) as potential predators of leaf roller larvae and egg masses (Lepidoptera: Torticidae) in central Washington apple and pear orchards. Pan-Pacific Entomology, 78:140-150.

7. Nyffeler, M. and G. Benz. 1987. Spiders in natural pest control a review. J. of Applied Entomology, 103: 321-329.

8. Nyffeler, M., R.G, Breene, D.A. Dean and W.L. Sterling. 1990. Spiders as predators of arthropod eggs. J. of Applied Entomology, 109:490-501. 
9. Peck, W.B. and W.H. Whitcomb. 1970. Studies on the biology of spider Chiracanthium inclusum (Hentz). Univ. of Arkansas (Fayetteville) Agricultural Experiment Station Bulletin 753: 76 pages.

10. Pfannenstiel, R.S. 2008. Spider predators of Lepidopteran eggs in South Texas field crops. Biological Control, 46: 202-208.

11. Rashad, A.M. and E.D. Ammar. 1985. Mass rearing of the spiny bollworm, Earias insulana on semi- artificial diet. Bull. Soc. ent. Egypte, 65: 239- 244.

12. Ruiz, R.I. 2006. Response of Chiracanthium inclusum spiderlings to kairomones associated with the eggs and scales of their prey, the cotton bollworm. M.Sc. Thesis, University of Texas at Pan American, Edinburgh, Texas, U.S.A.

13. Sallam , G.M.E. 1996. Studies on true spiders in Giza Governorate. M. Sc. Thesis, Fac. Agric., Cairo Univ., Egypt, PP.139.

14. Taylor, R.M. 2008. Plant nectar contributes to the survival, activity, growth and fecundity of the nectar-feeding wandering spider Chiracanthium inclusum (Hentz) (Miturgidae). Ph.D. Dissertation, Ohio State Univ., Columbus Ohio, U.S.A.

15. Turnbull, A.L. 1973. Ecology of the true spiders (Arancomorphae). Ann. Rev. Entomol., 18:305-348.

16. Whitcomb, W.H. and K. Bell. 1964. Predaceous insects, Spiders and mites of Arkansas cotton fields. Univ. of Arkansas (Fayetteville) Agricultural Experiment Station Bulletin 690: 84 pages.

17. Whitcomb, W.H., H. Exline and R. C. Hunter. 1963. Spiders of the Arkansas cotton field. Annals of the Entomol. Soci. America, 56:653- 660. 
تأثير الفرائس المختلفة علي المظاهر البيولوجية ومعدل التكاثر

\section{و الكفاءة الأفتراسية للعنكبوت Chiracanthium inclusum Hentz}

$$
\begin{aligned}
\text { معهر بحوث وقاية النباتات - مركز البراتيم أبو زيد - ميرفت عبد السميع قنديل - على أحمد السيد الزراعبة - الدقي - الجيزة }
\end{aligned}
$$

تم دراسة تاثير نوعين من الغذاء (الفر ائس) وهما دودة اللوز القرنفلية و دودة ورق القطن علي بعض المظاهر البيولوجية لدورة الحياة للاطوار الغير كاملة والأطوار الكاملة و الكفاءة التتاسلية وكذلك الكفاءة الأفتر اسية للعنكبوت C. inclusum تحت الظروف المعلية من درجة حرارة 25 ـ1

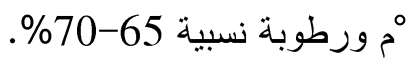

وقد اوضحت النتائج: قصر دورة الحياة للاطوار غير كاملة من العمر الثاني للمفترس و

حتي العمر السابع وخلال هذة المر احل استهلكت الأفراد كمية اكبر من دودة اللوز القرنفلية مقارنة بدودة ورق القطن. حيث تشير النتائج ان افضلية دودة اللوز القرنفلية للمفترس حيث مديث اعطت اعلي

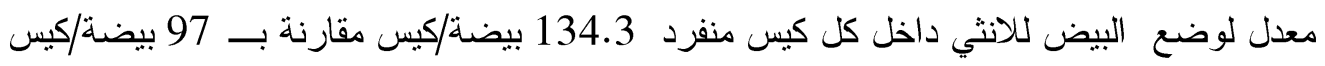
منفرد عند التغذية علي دودة ورق القطن الا ان منوسط حياة الطور الكامل كانت 114 يوم للانثي ، 75 يوم للذكر عند التغذية علي دودة اللوز القرنفلية مقارنة بـ 135 يوم للانثي و 98.3 يوم للذكر عند التغذية علي العمر اليرقي الثاني لدودة ورق القطن. 